\title{
The Passion of Lena Christ: From Fictionalized Autobiography to Biographical Novel
}

\author{
Mirjam Truwant \\ (Catholic University of Leuven)
}

\begin{abstract}
The aim of this paper is the comparative study of the diverse modes of identity-construction and myth-building centered on the figure of the German regional author Lena Christ (1881-1920). The research will take its starting point in a transmediatic corpus of (auto)biographic literature, as well as dramatic performance and film, whereby the main emphasis will be placed on the literary component. The highly tragic character of this Bavarian woman writer's existence, as described in her autobiography, formed the inspiration for two biographies (one of which written by Christ's second husband, himself an author), a film and more recently also novelized biography and a semi-fictional life-dramatization in the form of a theatre monologue. We will on the one hand study their cross-overs and divergences in character construction, generated by the difference in medium literary genre, intended effect, gender-related perception, and temporal distance. Another focus will be on the interplay between Lena Christ as both a (to different degrees) 'real' and fictional person, the means by which the transition from fact to fiction is achieved, and finally, especially with respect to the theatricalized version of the story of Christ's life, on the contrastive portrayal of her self-perceived existence, as illustrated by citations from her autobiography, and life as lived by her novels' protagonists.
\end{abstract}

'The infelicitous life and romantic death of the illegitimately born waitress, nun and writer, tormented by her mother and twice married' - with this melodramatic subtitle the 1968 tv-film The Lena Christ Case $e^{1}$ briefly summarizes the course of life of this early twentieth century Bavarian author and thereby situates itself entirely in the tradition of a rather problematic line of reception that successfully established itself immediately after her death in 1920, but especially from 1940 onwards, a line which until today largely invests the image of this woman.

The following historical overview of the successive constructions of the German author Lena Christ will first elaborate on the manner in which an autobiography may obstruct/construct the image of its author by balancing on the inherently problematic borderline between authenticity and performance. Subsequently, I show how an early biography can have a lasting effect on the later understanding of a writer and her works, when for decades, its distorting life portrayal and its myths of female subjectivity and authorship have been invariably rehearsed and some of its debatable contentions re-adopted. The final objective, however, is to show how the attempt of a present-day female

1 Hans W. Geissendorfer: 'Der Fall Lena Christ. Das ungeschickte Leben und der romantische Tod der unehelich geborenen, von ihrer Mutter gepeinigten, zweimal verheirateten Serviererin', Klosterfrau und Schriftstellerin (München: Bayrischer Rundfunk, 1968/69). 
writer to emend this mythologized image and to try and catch a more convincing glimpse of Lena Christ, simultaneously courts the danger of falling victim to the constraints of similar patterns, which equally reduce the biographical subject to a certain construct and fail to grasp its necessarily ever-escaping 'essence.'

It was in fact Lena Christ herself - this peculiar starting point makes this case the more interesting - who furnished the conditions of the possibility of a focus on the above mentioned tragic aspects of her life. When she was 30 she was prompted by her second husband Peter Benedix ${ }^{2}$ to depict the adverse fate she had suffered so far in an autobiography. Along general lines, this autobiography deals with Christ's earliest childhood with her grandparents in rural Bavaria at the close of the nineteenth century, her resettlement at the age of 7 with her newly-wed mother in Munich, where she then grows up as the daughter of innkeepers. The persistently tense relationship to her mother, from whose gross ill-treatment she suffers, induces her at the age of 17, when she already has several suicide attempts behind her, to enter a convent, where she will stay for one and a half years. At twenty she gets married; her husband soon turns out to be a violent alcoholic, and 7 years later she flees from this unhappy marriage with her 3 children. Consumptive and completely empoverished, she sinks to the lowest of social life. This is where the first part of Christ's life story ends, only shortly before she gradually works her way up again and meets Benedix - the beginning of her life as a writer, of a new existence which, however, does not end less dramatically than the preceding one.

Christ's life story, Memories of a Redundant Person, ${ }^{3}$ in which the conflictual mother-daughter relationship is the central focus, is, however, explicitly termed a novel, and this logically implies an occasional transgression of the dividing line between fact and fiction - a practice which is, in fact, already inherent to the genre as such, as every autobiography offers an opportunity for self-invention and self-transformation and displays only 'a version of the author's own life, anchored in verifiable biographical fact. ${ }^{4}$ Further, for autobiography, which, together with biography, traditionally occupies a position in the no-man's land between historiography and literature, the fictitiousness of fact for which Hayden White and the New Historicism have sharpened our awareness with regard to history in general, is even more obvious. Thus by

2 His original surname was Jerusalem, but this was changed into Benedix in 1937. Ghemela Adler, Heimatsuche und Identität. Das Werk der bairischen Schriftstellerin Lena Christ (Frankfurt a. M.: Peter Lang, 1991).

3 First edition: Lena Christ, Erinnerungen einer Überflüssigen (München: Albert Langen, 1912). We refer to the 2003 edition.

4 Paul Jalm Eakin, Fictions in Autobiography. Studies in the Art of Self-Invention (Princeton: Princeton UP, 1585). 
making use of narrative strategies such as the selection and arrangement of certain events, the facts of a life are turned into a plot. Christ explores the border-line position of this genre even further by turning her life story into a novelized autobiography, and she does so by, for instance, embellishing her account with situations or events which did not actually occur as she describes them, but which nonetheless clarify the general temporal and local context of the society she grew up in. ${ }^{5}$ Her most obvious manoeuvre to achieve a limited degree of fictionality is, however, providing her closest relatives with false names. Where the ethical motive for this intervention may be obvious - warranting the privacy of her next of kin -, the initial impetus for this move could also be a certain self-protection against possible allegations of non-veracity in depicting her mother's cruelty and her ex-husband's violence. By explicitly categorizing her autobiography as a novel, she may have claimed a degree of poetic licence, wanting to pre-empt accusations of untruthfulness (though the history of reception will prove such an intention to be in vain). As Leigh Gilmore makes clear, the relation of trauma to language is ambivalent, being both that which is beyond the representable, and that which has yet to be articulated in order to be overcome. Self-representation of trauma even seems a theoretical impossibility, the paradox being that where a trauma 'is typically defined as the unprecedented,' the autobiographical subject, by considering himself worth of becoming the subject of an autobiography, is supposed to be both 'unique and representative, ${ }^{6}$ a requirement Lena Christ's extraordinary life account cannot live up to. The life story of women in general already does not have a representative status, challenging the universalized middle-class male life-trajectory and the monopoly of the biographical hero as male hero. ${ }^{7}$ And as Gilmore further elucidates:

first person accounts of trauma by women, for example, are likely to be doubted... because their self-representation already is at odds with the account the representative man would produce. A first-person account of trauma represents an intervention in, even an interruption of, a whole meaning-making apparatus that threatens to shout it down at every turn. Thus a writer's turn from the primarily documentary toward the fictional

5 Just to give one example: whereas Christ in her novel alleges that her stepfather's father all in all had had 14 wives and 39 children, Goepfert reduces the number of marriages and offspring to 'only' 2 and 20 respectively. Christ, pp.57-59 and Günter Goepfert, Das Schicksal der Lena Christ (München: List Verlag, 1971).

6 Leigh Gilmore, The Limits of Autobiography. Trauma and Testimony (Ithaca: Cornell UP, 2001).

7 Anne-Kathrin Reulecke, 'Die Nose der Lady Haster', in Biographie als Geschichte, ed. by Hedwig Röckelein (Tübingen: Diskord, 1993). 
marks an effort to shift the ground of judgement toward a perspective she has struggled to achieve. ${ }^{8}$

Christ uses narrative techniques to create suspense: she focuses extensively on the episodes depicting the violent outbursts of her mother, whereas periods during which their coexistence obviously was more harmonious are merely summarized. The other taboo of domestic violence - intramarital sexual abuse - proves more difficult to be broken down: only a comparatively negligible number of pages is devoted to the description of the seven years Christ's first marriage lasted. By supplying only sparse details concerning her most intimate life, she fends off the voyeurism of the curious reader - but compensates for this frustration by heightening the dramatic tension of this last part of her novel by other means, by, for instance, letting herself give birth to 4 living and 2 stillborn children - that is at least one more child than the 3 living children actually attested. So Christ's autobiography has to be taken with a grain of salt, since it is a dramatized version of her life, just as the life as she actually lived it already was an artificial construct. ${ }^{9}$ In daily life Lena Christ was inscrutable; in her autobiography not less so. This fact in a way delivers the possibility of her remaining an unapproachable subject in the biographies to come.

This first literary achievement of Christ remained, though praised by the critics, largely unnoticed by the public. The same goes for a subsequent novel and collection of stories. Not until 1914 did she break through as an author, when she was the first to publish a series of sketches describing the everyday atmosphere following the outbreak of WWI - an accomplishment widely acclaimed for its authenticity and 'male fists, ${ }^{10}$ earning her a decoration from the Bavarian sovereign. Two more novels followed, and when she in 1920, in the middle of inflation, took her own life as a result of fear of an impending conviction for having forged paintings, she had acquired the status of a renowned author throughout Germany. Her death made the front pages, but all attention seemed to be directed towards the scandal surrounding her passing away. Benedix, who had played a dubious role in her far from romantic suicide, met the public's craving for sensation with an obituary elaborately dwelling on private matters, devoting no more than two sentences to her literary achievements. After Christ's death, he continued to obtain the bigger part of his income from the sales of her literary works, a state of affairs which easily explains why he promoted her works with fervour - thereby not shying

8 Gilmore, p.23.

9 It is exemplary that on the two occasions during her lifetime she was involved in a lawsuit, she unceasingly created new versions of the 'actual course of events' in an attempt to escape a penalty. Adler, pp.51-59 and pp.62-65.

10 Adler, p.90. 
away from gross exaggerations and distortions. In 1940, Benedix published a biography wherein he established a programmatic parallel between his first spouse and authors like Hölderlin and Kleist ${ }^{11}$ : the former mentally ill, the latter debt-ridden and driven to suicide at a young age, and both the creators of immortal compositions, initially being refused access to the canon, but eventually granted the prominent place in literary history they deserved..$^{12}$ So, on the one hand, Benedix creates this image of Christ as an ingenious story-teller, even worthy the more elevated denotation of "poet, ${ }^{13}$ while at the same time he disparages her as a woman who suffered from mental illness and hysterical fits associated with a maternal genetic predisposition, and even characterizes her as an ignorant creature from 'jenen Bezirk des Unbewußten [...], in dem Kinder und Tiere noch daheim sind [...], ${ }^{14}$ a naïve, natural talent driven by higher powers, unreflective, and free of any literary intentions. He stressed her rural ancestry in order to emphasize that had it not been for him, this unschooled woman never would have developed into a poet. He also does so because this image of the down-to-earth Bavarian regional writer complied with, first, his artistic, ideological, and political views, being a representative of the 'Heimatkunstbewegung," ${ }^{15}$ and, second, with his marketing strategy, in the service of which he also deployed the statements of Josef Hofmiller (18721933), once the most significant Christ critic. ${ }^{16}$

Benedix's biographical construction, created in the midst of the nationalsocialist era, started to lead its own, independent life. It resulted in stylization and mythologization, and would subsequently dramatically affect the history of Christ's after life and of her works' reception. Not only Benedix's subjectivity and his personal involvement with Christ were responsible for the kind of typology imposed on her, she was also stylized according to the

11 Peter Benedix, Der Weg der Lena Christ (München: Ludwig Baur Verlag, 1950).

12 Benedix, p.238.

13 Though not that gifted that she could assert herself in the male-connoted domain of drama, according to Benedix (Benedix, pp.155-156).

14 'The realm of the unconscious [...], where children and animals are at home' (Benedix, p.11).

15 Adler, pp.95-99. The 'Heimatkunstbewegung' was a turn of the century literary movement which, in reaction to modern civilization and metropolitan (decadent) literature, idealized peasantry and rural life, and thus prepared the ground for the later national-socialist blood and soil literature, which moved away from the orginal plea for a return to healthy, rural life and posited a connection between race and territory.

16 Hofmiller had recognized in Christ a female Ludwig Thoma (1867-1921, a famous Bavarian regional author and a contemporary of Christ), more closely tied to the farmer community by her blood than he was. This classification of her work as 'Literatur des heimlichen Deutschland' ('literature of the homely Germany'), suppressed by fashionable urban literature, was based on a fundamental misreading of her work as a peasant's idyll, in spite of the fact that she depicted rural life in all its harshness. Adler, p.27. 
models prevailing in this specific socio-cultural and literary context. ${ }^{17}$ It is not surprising, then, that Christ's literary production was successfully instrumentalised in the service of the national-socialist 'Blut und Boden' ideology, as a 1945 dissertation strikingly illustrates, as it draws on hereditary characteristics. ${ }^{18}$ The image of Christ as a madwoman on the one hand and the misunderstanding of her work as a glorification of pastoral life on the other, persisted after 1945, when in 1950 Benedix republished a hardly revised edition of his biography, in which only the names of a number of 'blood and soil' poets he had previously associated Christ with were eliminated. This version formed the basis of further reception, in, for instance, von Gugel's dissertation from 1959, which - although at times critical of Benedix's contentions - underwrites the hysterical and difficult character of Christ and tries to establish a link between her poetic disposition and her so-called 'tribal affiliation,' and in the above mentioned $1968 \mathrm{tv}$-film that, though formally experimental, derives its material exclusively from Christ's autobiography and Benedix's biography. ${ }^{19}$

In 1971, following the fiftieth anniversary of Christ's death, a change of course seemed to announce itself when Günter Goepfert promised an objective account of Lena Christ's life, intending to close some biographical gaps and basing himself on reliable sources, as opposed to the subjective, poetically alienated 'memories,' and the self-centred account of Benedix. Goepfert regarded his publication as the ultimate key to the destiny and the work of the - according to him - 'grandest old-Bavarian female poet. ${ }^{20}$ But appearances are deceptive, since Goepfert soon falls prey to a discourse that bears strong resemblance to Benedix's misogynist parlance.

Goepfert appears as a typical example of the modern mediating biographer, who promises genuine insight on the basis of a psychological character study. He includes himself into the story as a narrator, and makes use of strategies that should augment the impression of authenticity. ${ }^{21}$ Goepfert's problem, however, is that - though he promises a different and more reliable version than Benedix's - he largely draws on the latter's assertions and often states that 'we may well believe him,' even when there is no convincing reason to

17 Christian von Zimmermann, Fakten und Fiktionen. Strategien fiktionalbiographischer Dichtervorstellungen in Roman, Drama und Film seit 1970. Beiträge des Bad Homburger Kolloquiums, 21.-23. Juni 1999 (Tübingen: Gunter Narr, 2000).

18 Gertraud Troll, Lena Christ (München: Ludwig Maximilians Universität, 1945).

19 Adelheid Von Gugel, Lena Christ. Leben und Werk (München: Ludwig Maximilians Universität, 1959).

20 Goepfert, p.9.

21 Such as quotations, specifying dates, locations, sources, and references to the statements of contemporaries and previous biographers. Von Zimmermann, p.5. 
actually do so. At the same time he often casts doubt on Christ's own account, and he does so implicitly on the basis of Benedix's characterisation of her as a hysterical psychopath. Christ is thus alleged to suffer from a false memory, and even though Christ's Memories is a novel, he subjects it to 'a literal truth test, ${ }^{22}$ wanting to convert her story of trauma into a representative life account. Her mother's violent fits of temper are partly acknowledged, partly reduced to a parental practice generally accepted within the specific social class she belonged to (lower middle class) and typical of their geographical and historical context. The sexual aggression of her first husband he interprets as 'wishes and expectations' 'most young potent men' have, thus placing the blame for the failed marriage exclusively with Christ's physical and mental constitution. ${ }^{23}$

Goepfert's biography has proven to be as tenacious as the myths installed by Benedix, since four revised editions have succeeded the publication of 1971 , the last amended version dating from as recently as 2004 . In the meantime, however, there have been several attempts to do more justice to the life and work of Christ. In 1991, a dissertation was dedicated to an urgently needed thorough examination of Christ's literary legacy, ${ }^{24}$ and in 2002 two other women independently offered an artistic approach, this time to shed a new light on the person of Christ. Both convert her into a doubly fictional figure, by creating a patchwork of life story and novel extracts. ${ }^{25}$ I will here focus on the biographical novel by Asta Scheib, entitled In the Gardens of the Heart.

Biographical fiction has not been a marginal phenomenon the past thirty years, and it cannot be deemed coincidental that the exponential upsurge of women writing (about) women's biographies coincided with the beginnings of the feminist movement in the 1960s. ${ }^{26}$ What those novels with a historical woman as a protagonist have in common is the "attempt to "rehabilitate" them

22 Gilmore, p.14.

23 Goepfert, pp.24, 27, 36, and 64.

24 In her preliminary remarks, Adler emphasizes that previously, the prevailing focus on the reflection of autobiographical issues in Christ's work led to the equation of life and work, the preoccupation with her tragic fate and the neglect of a more theoretical approach of her writings (Adler, p.13). This statement affirms Anita Runge's conclusion that especially women's writings are highly susceptible to the tendency of being interpreted autobiographically, being commonly considered to be drawn from life. Anita Runge, 'Geschlechterdifferenz in der literaturwissenschaftlichen Biographik. Ein Forschungsprogramm', in Grundlagen der Biographik. Theorie und Praxis des biographischen Schreibens, ed. by Christian Klein (Stuttgart: Metzler, 2002), p.114.

25 I will not go deeper into the first artistic 're-creation', Bettina Mittendorfer's successful theatre monologue The Dream of Lena Christ (script by Jörn van Dyck), which earned the actress an award.

26 Anne-Kathrin Reulecke. 'Die Nase der Lady Hester', in Biographie als Geschichte, ed. by Hedwig Röckelein (Tübingen: Diskord, 1993), pp.117-142 and 132. 
by granting them a voice; ${ }^{27}$ an ambition Asta Scheibs emotionally motivated agenda underwrites. ${ }^{28}$ Although Lena Christ at one time actually had a voice, she only had one for the period reaching up to her late twenties. For what happened in her life afterwards, we are largely dependent on Benedix's testimony, and it is exactly against this highly questionable testimony that Scheib raises a corrective voice. A prerequisite to succeed in annihilating the pertinacious Christ-myth is the rectification of Benedix, and Scheib's intention is exactly to expose the malignancy of this disreputable character who highly influenced Christ (and her image). ${ }^{29}$ This implies a modification of Bird's rather general comment on women-centered biographical novels that 'women hitherto largely known only through their association with great men were being rediscovered. ${ }^{30}$ Since Benedix, a wannabe author, had always stood in the shadow of his gifted wife, ${ }^{31}$ but nonetheless simultaneously had had control over the myth construction of her, it would in Christ's case be more appropriate to say that she was a woman 'hitherto largely known through the image-making of a man, himself hitherto largely known only through his association with a great woman.' Together with Bird we can indeed observe how 'in fictional representations, the relation of the woman to the male subject itself seems to be of central concern.' ${ }^{32}$ The configuration Lena-Peter needs to be remodelled and the degree of mutual dependency redefined. To achieve this, Scheib deploys diverse strategies, of which I will only briefly mention some.

A first strategy is the attempted filling-out of biographical gaps with new characters the task of which it is to expand Christ's social environment. Lotte Pritzel, a historical avantgarde artist whose contact to Christ is possible but not documented, ${ }^{33}$ seems to be a figure of central importance. Together with the artistic circle she belongs to, this succesful doll maker and costume designer constitutes an artistic, ideological and social antipode to the conservative and whimsical Benedix and allows Christ a partial escape from his sole influence.

27 Stephanie Bird, Recasting historical women. Female identity in German biographical fiction (Oxford: Berg, 1998), p.1.

28 Asta Scheib in her e-mail to me from May 10, 2005.

29 Asta Scheib in her e-mail to me from May 10, 2005.

30 Bird, pp.4-5.

31 The fact that der Weg der Lena Christ occasionally digresses on episodes that solely concern Benedix are a clear indication that this was indeed so, and he must have seen this biography as an ideal opportunity for self-portrayal and for directing the spotlight on himself.

32 Bird, p.5.

33 Pritzel was befriended to the notorious writer Franziska Gräfin zu Reventlow, who in her turn had the same editor as Lena Christ, Korfiz Holm. See Reventlow's diary entry for Tuesday, 29 March, 1910, available at: </http://www.wolfgang-rieger.de/OnlineTexte/Reventlow/Tagebuecher/Tagebuecher9.htm/>. 
Another strategy is to stress Lena's standard of knowledge, which was not as low as Benedix preferred to make it appear. Scheib also emphasizes the authority Christ gains both socially and within the literary system as a recognized writer and additionally directs the attention to her artistic disposition in fields other than the literary. A further strategy is to partly rewrite certain events as described in Benedix's biography, so as to give them an entirely opposite denotation and to cast a more deprecatory light on the role of Peter Benedix.

The episode which most strikingly illustrates this is a scene of hypnosis, regarded by Benedix as cogent proof of Christ's supernatural powers. Benedix seemed to be convinced - on paper anyway - that Christ was a highly suggestible person, whom he could easily hypnotize. On the basis of his observations, he concluded that her literary activity, which he interpreted as 'écriture automatique,' was executed in a state of trance, and Hofmiller's statement 'nicht sie, sondern es schreibt ${ }^{34}$ could perfectly underwrites this image construction of an hysterical and naïve natural genius. In reality, a phase of intensive study of sources and preparatory work preceded each writing process, as some documents and early manuscripts attest. ${ }^{35}$ With historical hindsight, when such theories of hypnosis and hysteria no longer hold the same scientific significance as in the fashionable turn of the century psychiatric discourse - which Benedix, a former student of medicine, was familiar with - it is rather he who appears as being naïve. And this is exactly what Asta Scheib takes advantage of in order to dethrone Benedix - not without a hint of sarcasm. ${ }^{36}$ Beaten with his own rod, he is thrust into the role originally reserved for Christ, while she, by playing fossum to grant him the childlike pleasure of hypnotizing, takes control over the situation and gains the superior position.

A last intervention by Scheib to be highlighted is the occasional reversal of the power-ratio within Benedix and Christ's relationship. This is most obvious when some aspects of the Christ-myth are simply projected back onto Benedix. On top of the childish-naïve behaviour just mentioned, Benedix is elsewhere also explicitly referred to as a hysteric, tormented by daemons and subconscious drives. ${ }^{37}$ Thus precisely the most persistent Christ-myth turns itself against its creator and thereby forces him into a female connoted position

34 Hofmiller, as quoted in Benedix, p.132.
35 Adler, p.70.
36 There is also a faint echo of deceptive experiments with hysterics pretending to be successfully
hypnotized as they took place at the end of the nineteenth century in the Parisian mental asylum
La Salpétrière under the direction of Charcot.
37 Asta Scheib, In den Gärten des Herzens. Die Leidenschaft der Lena Christ (München: dtv.

37 Asta Scheib, In den Gärt
2004), pp. 195 and 350. 
and makes him appear ridiculous. ${ }^{38}$ As the genre description of A.H. Schmitz's comedy from 1914, 'der hysterische Mann. Lustspiel in drei Aufzügen' clearly suggests, a hysterical man could only be an object of derision. Also in a number of other respects, Benedix occupies the 'female' position: he is financially supported by a female author, whose writings are by some critics categorized as astonishingly male, and he is devaluated to a mere assistant and supposed to help the woman who initially did his writing work 'bei wichtigen schriftstellerischen Arbeiten. ${ }^{39}$ In this context it may be illuminative to refer to Goldstein and the parallel he draws between hysteria as a malfunction of the female procreative organs and hysteria as a failure of male artistic creativity. Goldstein quotes Flaubert, who claimed that 'the simple act of writing installs hysteria in [his] head,' thereby illustrating the inhibiting impact a hysterical state of mind has on one's capacity of verbal expression. ${ }^{40}$ The line that can be drawn from this conclusion to Benedix as a failed writer seems obvious. The power-ratio thus has been gradually reversed, and the master-subordinate relationship subsequently ironised. 'Herr' Benedix is turned into a 'Herrli,'41 and whereas this form of address is a real - and neutrally - transmitted one, it is used by Scheib to challenge Benedix's masculinity and dominance. ${ }^{42}$

This last example illustrates how Scheib cannot escape thinking in binary oppositions by simply inverting the situation, and thus recreates as essentialist a picture as Benedix or Goepfert before her. Her endeavour to furnish a correction of the Christ-myth also collapses in a number of other respects. Already the title - In the Gardens of the Heart. The Passionate Life of Lena Christevokes some stereotypical concepts traditionally associated with womanhood - not exactly the best of choices for a novel which tries to deconstruct a writer's image consisting of exactly such notions. Asta Scheib continues - already in the title - a line of reception she actually wanted to break with. Also 'the biographical illusion' - to speak with Bourdieu - of Christ's life as a necessary, predestined catenation of events pointing towards an inescapable tragical ending is shared with the anteceding Christ biographers, who retrospectively impose meaning on Christ's existence. Or as Scheib stated in an interview:

38 The hysteria discourse has always been, and more so during the 'age of nervousness' (i.e., at the turn of the century), sex-differentiated: the disorder which with regard to women was commonly reckoned to be naturally caused hysteria was in the case of male patients diagnosed as the civilization disease neurasthenia. Benedix himself uses the term 'Nerven' for his selfcharacterization without reservation. Benedix. p.31.

39 'with important literary activities' [my translation]. Scheib, p.323.

40 Jan Goldstein, 'The Uses of Male Hysteria: Medical and Literary Discourse in Nineteenth Century France', Representations, 34 (1991), p.43.

41 Distorted diminutive form of 'Sir', also used to refer to a male petowner.

42 Goldstein, p.115. 
Ich beschäftige mich mit Menschen, die in ein Leben hinein geboren wurden, das ihnen nicht gemäß ist. Auch nach menschlichen Maßstäben nicht. Lena Christ hatte keine Chance. [...] Ohne München wäre sie früher zerbrochen. Sie hatte keine Chance. ${ }^{43}$

In other words: she was predestined to tragedy from earliest childhood, her doom was determined by the essence of her being and in the end not alterable (only restrictedly delayable) by circumstantial factors. Such a view on life does not leave much space for personal development nor for time-differentiation. ${ }^{44}$ Rather than showing progression, Christ's lifeline seems to be intersected by constantly recurring basic constellations and key-events: this allows for a reading of for instance her relationship to Benedix as just a reenactment of the earlier exploitation by her mother, and the figure of Dr. Kerschensteiner, the renowned historical pneumologist who treated Christ's TB, then appears as only an incarnation of Christ's early love, a young priest, just as the lute-player Fabbri, whom she had an affair with, in his turn will embody Kerschensteiner.

This same figure of Dr. Kerschensteiner, who here appears as a positive opponent of Benedix and as the object of Christ's platonic love, poses another problem. On the one hand, he, the new authoritative voice of science, is supposed to restrict Benedix's influence, but, on the other hand, the now partly dissolved creative and existential dependence of Christ on Benedix is simply replaced by a mainly emotional dependence on the scientist. So when in Scheib's novel it is no longer Benedix but Kerschensteiner who initially encouraged Christ to put down her turbulent life account in writing, this does not change anything about the basic fact that she in neither case appears as an autonomous writer, since the actual impetus for this creative activity is situated outside of her.

Kerschensteiner not only figures as the one Lena writes for, but also as the one person she ardently loves and in whose presence she can reach a sense of wholeness. The same goes for her publisher Korfiz Holm and lover Fabbri, who functions as a mere substitute for the unattainable Kerschensteiner. Thus only in the relationship to a man, '[der] ihren Leib und Seele zusammen[hält] ${ }^{45}$ can

43 'I deal with people who were born into a life that does not fit them. Not to human norms either. Lena Christ did not stand a chance. [...] Without Munich she would have succumbed earlier. She did not stand a chance [my translation].' Interview with Brigitte Gießler of 15.9.2002 for bayrische Rundfunk online: <http://www.br-online.de/kultur/literatur/lesezeichen/20020915/20020915_4. html>.

44 The stronger the tendency towards life-mythologization, the less time is differentiated. Peter André-Alt, 'Mode ohne Methode? Überlegungen zu einer Theorie der literaturwissenschaftlichen Biographik', in Grundlagen der Biographik. Theorie und Praxis des biographischen Schreibens, ed. by Christian Klein (Stuttgart: Metzler, 2002).

45 Scheib, p.366: '[who] holds together her body and soul.' Another example can be found on p.288. 
she find access to her inner-self. This image of female subjectivity - woman as a castrated entity, as lack, nothingness, as a void to be filled - echoes early, and from a present-day point of view highly debatable psychoanalytical thinking. And even though Christ really may have uttered such thought in one of her letters ${ }^{46}$ one has to keep in mind that even ego-documents do not consist of private reality, but are themselves the product of societal gender- and sexuality discourses. ${ }^{47}$

Christ's secret passion for her doctor, uncomfortably reminiscent of the stock themes of cheap romance, is only one of a number of gaps with a certain degree of 'sensation potential' which are colourfully filled in. Other examples worth mentioning are Christ's convent-friendship with Sister Cäcilia, which in this novel has been transformed into a forbidden lesbian love-affair, the vividly described rape and maltreatment of Christ by her first husband, her secret erotic phantasies about Dr. Kerschensteiner and the bed scenes with her lover Fabbri. All of these mercilessly degrade Lena Christ to the object of the maleconnoted voyeuristic gaze of the reader, which is nearly as suppressive as the mythologized position Scheib wants to save her from. ${ }^{48}$

On the basis of the above mentioned essentialist 'relapses' we can conclude that Asta Scheib does not seem to entirely succeed in her restorative enterprise. What In the Gardens of the Heart mainly lacks is a self-reflexive handling of narrative models and biographical information which exposes the constructedness of the novel and would arguably more drastically critique the unacknowledged constructedness of the earlier biographical efforts. The failure of such an enterprise can primarily be ascribed to the author's unreflective sympathy for the protagonist, since total empathy and blindness for the specificity of a certain historical setting prevent an effective dialogue with the past. ${ }^{49}$ The use of an absent third-person omniscient narrator increases the impression of reality and also prompts the reader to a naïve identification with the protagonist and to the unresistant absorption of so-called facts.

Bird brands such a narratorial approach 'hermeneutically reactionary' and pleads for a mode which relativizes the role of the creative author and valorizes

\footnotetext{
46 Lena to Benedix: 'I was only worth something thanks to you, and I have been reduced to a nobody, since I have not got you any longer. I am anchorless, feeble and lifeless [my translation].' Goepfert, p.120.

47 Schmidt, p.144.

48 So Reulecke's finding that hierarchies of meaning and patterns of feminity systematically catch on in biographies appears easily applicable to this case, where the female protagonist is regularly reduced to pure physicality. Reulecke, p.131.

49 Dominick LaCapra, cited in Bird, pp.19-20.
} 
that of the reader, who should be actively involved in a subversive reading. ${ }^{50}$ According to Felman:

[gilt] die ideale Leserin als den Verfasserinnen und Verfassern von Texten ebenbürtige dekonstruktivisch orientierte Theoretikerin, die durch ihre Lektüre eine Defiguration des Geschlechterverhältnisses vornimmt und damit dessen Rekonstruktion einleitet. ${ }^{51}$

There are several possible ways out of dead-end biographical constructs for the author. The solution Toril Moi suggests is a 'personal genealogy' which should replace a narrative and linear life-description by a reconstruction of the complex network of power-based and subject-generating intertexts. ${ }^{52}$ Such a mode of proceeding may especially be profitable to discuss women's lives, because it undermines traditional discourses of knowledge:

When the overlapping ground between the categories of fiction, social history, psychological observations, and sociological insight is recognized as fertile [rather] than dangerous, for a biographer, because it contains contradictions in the very roots of knowledge, it can work very well for women whose lives also contradict the validity of this knowledge. ${ }^{53}$

Another conceivable answer to the biographical problem is - even though some think that this may degrade the result to a mere mechanical product ${ }^{54}$ - biographical metafiction or quest-biography in which the thematization of biographical work itself is of central concern. ${ }^{55}$ This necessarily exposes the role of the biographer and his affinity to the biographical object and warns the reader not to fall into the trap of absolute truth claims, for, as Freud al-

50 Bird, p.148.

51 'the ideal reader is a deconstructively orientated theoretician, who is equal to the authors of texts, and who, while reading, defigures the gender ratio and thus induces its reconfiguration' [my translation] (Felman as referred to by Rinnert, 2002, p.121).

52 Runge, p.119.

53 Terese Iles, cited in Runge, p. 120.

54 Herman Kurzke, 'Zur Rolle des Biographen. Erfahrungen beim Schreiben einer Biographie', in Grundlagen der Biographik. Theorie und Praxis des biographischen Schreibens, ed. by Christian Klein (Stuttgart: Metzler, 2002), p.173.

55 von Zimmermann, p.6. 
ready understood, writing the story of one's life equals committing oneself to deception. ${ }^{56}$

A successful attempt at writing a fictional biography, we may conclude, postulates a transparency of how source material is incorporated into a fictional frame and should display the author's self-relativisation and increase the awareness of the reader towards constructions of subjectivity, instead of, like Asta Scheib, trying to create an airtight image and suggesting its reality, only to eventually and inevitably fail in this utopian enterprise.

56 'Whoever becomes a biographer, commits himself to lying, to concealment, hypocrisy, whitewashing and even to dissembling his lack of understanding, because biographical truth is unattainable, and if it would be up for grabs, it would be useless' [my translation]. Freud, quoted in Thomas Anz, 'Autoren auf der Couch? Psychopathologie, Psychoanalyse und biograhisches Schreiben', in Grundlagen der Biographik. Theorie und Praxis des biographischen Schreibens, ed. by Christian Klein (Stuttgart: Metzler, 2002), pp.87-106. 


\section{Bibliography}

Adler, Ghemela, Heimatsuche und Identität. Das Werk der bairischen Schriftstellerin Lena Christ (Frankfurt a.M.: Peter Lang, 1991).

André-Alt, Peter, 'Mode ohne Methode? Überlegungen zu einer Theorie der literaturwissenschaftlichen Biographik', in Grundlagen der Biographik. Theorie und Praxis des biographischen Schreibens, ed. by Christian Klein (Stuttgart: Metzler, 2002).

Anz, Thomas, 'Autoren auf der Couch? Psychopathologie, Psychoanalyse und biograhisches Schreiben', in Grundlagen der Biographik. Theorie und Praxis des biographischen Schreibens, ed. by Christian Klein (Stuttgart: Metzler, 2002).

Benedix, Peter, Der Weg der Lena Christ (München: Ludwig Baur Verlag, 1950).

Bird, Stephanie, Recasting historical women. Female identity in German biographical fiction (Oxford: Berg, 1998).

Christ, Lena, Erinnerungen einer Überflüssigen (München: dtv, 2003) pp.57-59.

Eakin, Paul John, Fictions in Autobiography. Studies in the Art of Self-Invention (Princeton: Princeton UP, 1985).

Gilmore, Leigh, The Limits of Autobiography. Trauma and Testimony (Ithaca: Cornell UP, 2001).

Goepfert, Günter, Das Schicksal der Lena Christ (München: List Verlag, 1971).

Goldstein, Jan, 'The Uses of Male Hysteria: Medical and Literary Discourse in Nineteenth Century France', Representations, 34 (1991), pp.134-165. p.143.

Klein, Christian, ed., Grundlagen der Biographik. Theorie und Praxis des biographischen Schreibens (Stuttgart: Metzler, 2002).

Kurzke, Herman, 'Zur Rolle des Biographen. Erfahrungen beim Schreiben einer Biographie', in Grundlagen der Biographik. Theorie und Praxis des biographischen Schreibens, ed. by Christian Klein (Stuttgart: Metzler, 2002) .

Reulecke, Anne-Kathrin, 'Die Nase der Lady Hester', in Biographie als Geschichte, ed. by Hedwig Röckelein (Tübingen: Diskord, 1993).

Runge, Anita, 'Geschlechterdifferenz in der literaturwissenschaftlichen Biographik. Ein Forschungsprogramm', in Grundlagen der Biographik. Theorie und Praxis des biographischen Schreibens, ed. by Christian Klein (Stuttgart: Metzler, 2002).

Scheib, Asta, In den Gärten des Herzens. Die Leidenschaft der Lena Christ (München: dtv, 2004). 
Schmidt, Gary, 'Literarische Deutungen eines Lebens und biographische Interpretationen eines Textes: Der Tod in Venedig in Thomas-Mann-Biographien', in Grundlagen der Biographik. Theorie und Praxis des biographischen Schreibens, ed. by Christian Klein (Stuttgart: Metzler, 2002).

Troll, Gertraud, Lena Christ (München: Ludwig Maximilians Universität, 1945).

Von Gugel, Adelheid, Lena Christ. Leben und Werk (München: Ludwig Maximilians Universität, 1959).

Von Zimmermann, Christian, ed., Fakten und Fiktionen. Strategien fiktionalbiographischer Dichtervorstellungen in Roman, Drama und Film seit 1970. Beiträge des Bad Homburger Kolloquiums, 21-23 Juni 1999 (Tübingen: Gunter Narr, 2000). 
Kamuf, Peggy, Signature Pieces. On the Institution of Authorship (Ithaca, New York: Cornell University, 1988).

Marcus, Laura, Auto/biographical Discourses. Theory, Criticism, Practice (Manchester: Manchester University Press, 1994).

Moriarty, Michael, Roland Barthes, $2^{\text {nd }}$ edn (Cambridge: Polity Press, 2004). 